\title{
KONSEP HUKUM PIDANA ISLAM DAN SANKSINYA DALAM PERSPEKTIF AL-QUR'AN
}

\author{
Sunarto \\ Institut PTIQ Jakarta \\ Email : sunartoindana@gmail.com
}

\begin{abstract}
Abstrak : Sebagai sumber hukum utama dalam Islam, al-Qur'an telah mendeskripsikan berbagai macam pelanggaran kepidanaan beserta sanksi hukumannya yang disebut Jarimah. Hal ini relevan dengan tujuan disyariatkan hukum-hukum Allah di muka bumi ini untuk kemaslahatan dan kebahagiaan manusia itu sendiri. Ketentuan sanksi yang Allah berikan kepada si pelaku aniaya bukan bermaksud untuk membalas dendam terhadap apa yang telah ia lakukan, melainkan untuk pemenuhan hak Allah dan hak keluarga teraniaya sebagai bentuk keadilan, memberikan efek jera dan perlindungan publik. Sebagai mukallaf hendaknya manusia patuh dan tunduk terhadap aturan syari'ah yang telah Allah tetapkan dalam al-Qur'an agar selamat dari sanksi baik di dunia maupun di akhirat.
\end{abstract}

Kata Kunci: Hukum Pidana Islam; Jarimah; qishash; kemaslahatan.

\section{Pendahuluan}

Islam adalah agama pembawa nilai-nilai rahmatan lil'alamin, selaras dengan orentasi syariat yaitu untuk kemaslahatan umat. Allah swt. menurunkan al-Qur'an ke muka bumi ini sebagai pedoman hidup bagi manusia yang harus ditaati dan dapat diaplikasikan ke dalam dunia nyata, agar manusia mendapatkan kebahagiaan baik di dunia maupun akhirat.

Syari'at diturunkan Allah swt. dalam bentuk tuntutan taklifi, baik berupa tuntutan perintah (أمر), maupun tuntutan larangan (نهي), dengan tujuan untuk merealisasikan kemaslahatan. Secara spesifik pembebanan syari'at bagi mukallaf, ditujukan atas lima hal, yaitu: pemeliharaan agama, jiwa, akal, keturunan dan harta. ${ }^{1}$ Ketika lima asas tersebut tidak terpenuhi, terusik, maka kemaslahatan, keselamatan dan perkembangan individu manusia, keteraturan sosial dan kesejahteraan masyarakat menjadi mustahil didapatkan. Jadi bila satu diantara lima perkara tersebut tidak terpenuhi berakibat fatal dalam

${ }^{1}$ Ali Hasballah, Ushul al-Tasyri' al-Islami, Mesir: Dar al-Ma'arif, t.t., hal. 296. Lihat pula 'Abdul Wahab Khalaf, 'Ilmu Ushul Fiqh,Kairo: Dar al-Hadits, 2003M/ 1423H. hal. 231232. 
kehidupan manusia. Atas dasar ini segala tindakan yang dapat mewujudkan perkara tersebut harus (wajib) dilakukan, sebaliknya setiap tindakan yang dapat menghalanginya harus dihindarkan (diharamkan). Segala tindakan yang mengancam eksistensi terwujudnya lima asas tersebut dinamakan tindak pidana Islam (Jarimah).

Pada kesempatan kali ini penulis ingin mendeskripsikan tentang tindakan-tindakan pidana dalam Islam dan akibat hukumnya sebagaimana yang termuat dalam al-Quran, dengan rumusan masalah sebagai berikut:

1. Apa pengertian Hukum Pidana Islam (Jarimah) itu?

2. Tindak Pidana Islam apa saja yang termasuk dalam cakupan al-Qur'an?

3. Apa manfaat dan tujuan ditunaikannya qishash / had bagi manusia?

\section{A. Pengertian Hukum Pidana Islam}

Hukum Pidana Islam atau dalam istilah Fikih disebut Hukum Jinayat atau Jarimah. Jarimah bersal dari bahasa Arab (جريمة), yang berarti perbuatan dosa atau tindak pidana. Dalam terminologi hukum Islam, Jarimah dapat diartikan sebagai perbuatan-perbuatan yang dilarang menurut syara' dan ditentukan hukumannya oleh Allah, baik dalam bentuk sanksi-sanksi yang sudah jelas ketentuannya ( $\mathrm{had}$ ) maupun sanksi-sanksi yang belum jelas ketentuannya oleh Allah (ta'zir).

Tindak pidana (jarimah) yang dapat mengancam lima asas dalam Islam tersebut dapat diklasifikasikan ke dalam dua macam. Pertama, tindak pidana yang mengganggu kepentingan pribadi (haqqul adami), kedua, tindak pidana yang mengganggu kepentingan public (haqqullah). Yang pertama, berkaitan dengan kehormatan nyawa dan anggota tubuh manusia, kedua berhubungan dengan kehormatan agama, keturunan dan keamanan public. ${ }^{2}$ Penempatan jenis hukum pidana Islam baik berupa hak manusia maupun hak Allah semata, hanya untuk mempertimbangkan kepentingan mana yang lebih dirugikan, dan siapa yang berwenang dalam proses eksekusi terhadap pelaku tindak pidana. ${ }^{3}$

Dalam pembahasan mengenai tindak pidana kejahatan beserta sanksi hukumannya disebut dengan istilah Jarimah atau Uqubah. Jarimah dapat dibedakan menjadi dua hal, yaitu Jinayah dan Hudud. Jinayah membahas tentang pelaku tindak kejahatan beserta sanksi hukuman yang terkait dengan pembunuhan yang meliputi: qishash, diyat dan kafarat. Sedangkan hudud membahas tentang pelaku tindak kejahatan selain pembunuhan, yaitu: perihal penganiayaan beserta sanksi hukumannya yang meliputi: zina, qadzaf, mencuri, miras, merampok dan bughah (begal).

${ }^{2}$ Abu Hamid Ahmad Musa, al-Jaraim wa al-Uqubat fi al-Syari'ah al-Islamiyah, Kairo: Jami' ah al-Azhar, 1975, hal. 36-37.

3 'Abdul Qadir 'Audah, al-Tasyri' al-Jina'I al-Islami, Bairut: Muassasah al-Risalah, 1993, hal. 206. 


\section{B. Jinayah Dalam al-Qur'an}

Jinayah dalam al-Qur'an diklisifikasin atas tiga hal:

\section{Jarimah Qishash}

Hukuman mati dalam pidana Islam dikenal dengan istilah qishash. Secara etimologis qishash berasal dari bahasa Arab: قصّ، بقصّ ، قصصان = qasha-yaqushu-qashashan ) bermakna: "تتبعُ للأثر " "megikuti jejak”. Sementara kata: ("القصنصنُ" = Al-qashashu): bermakna bekas/ jejak. Hal tersebut semakna dengan firman Allah QS. al-Kahfi: 64" فارتدّ على أثرهما قصصا " “' "Lalu keduanya kembali, mengikuti jejak mereka semula." Dari akar kata yang sama lahir kata qishah (kisah) karena "Orang yang berkisah mengikuti peristiwa yang dikisahkannya tahab demi tahab sesuai dengan kronologis kejadiannya," sebagaimana tertuang dalam beberapa ayat al-Qur'an misalnya QS. Ali Imran: 62 "Sesungguhnya ini adalah kisah yang nyata." dan pada surat yang lainnya. ${ }^{5}$

Sementara qishash sendiri bermakna: mengikuti, membalas penumpahan darah dengan bentuk perbuatan yang sama. ${ }^{6}$ Ibnu Munzir dalam "Lisanul Arab" mendefinisikan qishash:

77، suatu hukuman yang ditetapkan dengan cara mengikuti bentuk tindak pidana yang dilakukan, seperti bunuh dibalas dengan bunuh, melukai dibalas melukai. Muhammad Ali al-Sais dalam tafsirnya "Tafsir Ayat al-Ahkam" menginterpretasikan qishash diperlakukan sama dengan apa yang dilakukan. Ketika seseorang diperlakukan seperti apa yang dia lakukan, maka itu akan memeberikan bekas kepadanya. ${ }^{8}$

Jaraimul Qishash, adalah kejahatan yang dapat dikenai hukuman qishash atau diyat. Qishash artinya balasan yang sepadan, yaitu hukuman yang dijatuhkan kepada pelaku seperti perbuatan yang telah dilakukannya kepada korban. Misalnya hukuman bagi pembunuh di-qishash dengan cara dibunuh, hukuman bagi pelaku yang melukai yang menyebabkan orang lain cacat diqishash seperti perbuatannya misalnya : qishash mata dengan mata, tangan dengan tangan, dan seterusnya.

Qishash diatur dalam al-Quran antara lain:Firman Allah swt. dalam QS. al-Maidah, 5:45

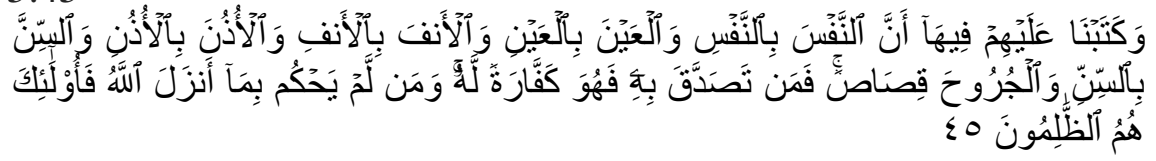

${ }^{4}$ Al-Raghib al-Asfahani, Mufradat alFazh al-Qur'an, Bairud: Dar al-Syammiyah, t.t, cet. III, hal. 671 .

${ }^{5}$ Beberapa makna "kisah" dalam al-Qur'an antara lain: QS. al- 'Araf: 7; QS. Yusuf: 3; QS. al-qashash: 25 .

${ }^{6}$ Al- Asfhani, Mufradat, h. 672.

${ }^{7}$ Ibnu Manzur, Lisan al- 'Arab, Bairud: Dar Shadir, t.t, Juz VII, hal. 73.

${ }^{8}$ Muhammad Ali, Tafsir Ayat al-Ahkam, Bairud: Dar ibnu Katsir, t.t, Jilid II, hal. 129. 
"Dan Kami telah tetapkan terhadap mereka di dalamnya (At Taurat) bahwasanya jiwa (dibalas) dengan jiwa, mata dengan mata, hidung dengan hidung, telinga dengan telinga, gigi dengan gigi, dan luka luka (pun) ada qishaashnya. Barangsiapa yang melepaskan (hak qishaash)nya, maka melepaskan hak itu (menjadi) penebus dosa baginya. Barangsiapa tidak memutuskan perkara menurut apa yang diturunkan Allah, maka mereka itu adalah orang-orang yang zalim."

Dalam QS. al-Baqarah, 2:178

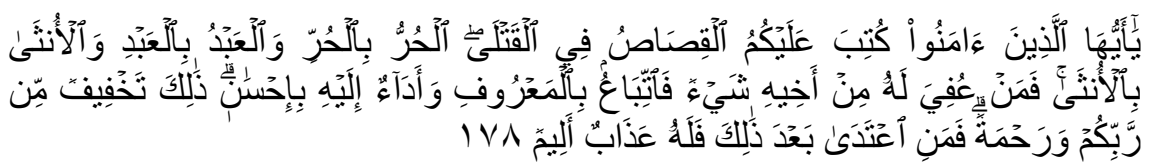

"Hai orang-orang yang beriman, diwajibkan atas kamu qishaash berkenaan dengan orang-orang yang dibunuh; orang merdeka dengan orang merdeka, hamba dengan hamba, dan wanita dengan wanita. Maka barangsiapa yang mendapat suatu pemaafan dari saudaranya, hendaklah (yang memaafkan) mengikuti dengan cara yang baik, dan hendaklah (yang diberi maaf) membayar (diat) kepada yang memberi maaf dengan cara yang baik (pula). Yang demikian itu adalah suatu keringanan dari Tuhan kamu dan suatu rahmat. Barangsiapa yang melampaui batas sesudah itu, maka baginya siksa yang sangat pedih."

Ibnu Katsir menyebutkan dalam tafsir asbabul nuzul ayat ini. Imam Abu Muhammad ibnu Abi Hatim meriwayatkan, "Telah diinformasikan kepada kami oleh Abu Zahrah, Yahya bin Abdullah ibnu Bukair, Abdullah ibnu Luhi'ah dan Atha' ibnu Dinar dari Said ibnu Zubair mengenahi firman Allah, "Hai orang-orang yang beriman, diwajibkan atas kamu qishaash berkenaan dengan orang-orang yang dibunuh; orang merdeka dengan orang merdeka." Mereka mengatakan, bahwa pada waktu itu ada dua suku saling perang pada masa Jahiliyah, beberapa waktu sebelum datangnya Islam. Maka diantara mereka terjadi pembunuhan dan pelukaan, sehingga mereka membunuh budakbudak dan kaum wanita, kemudian sebagian mereka tidak membalas atas sebagian yang lain sampai datangnya Islam. Diantara suku itu ada yang bertindak melampaui batas dalam jumlah dan harta. Lantas mereka melakukan perjanjian internal, bahwa mereka tidak rela sehingga membunuh orang merdeka sekalipun mereka membunuh budak saja, dan membunuh laki-laki meskipun mereka membunuh perempuan. Kemudian turunlah ayat di atas, 
"Orang meredeka dibalas orang merdeka, budak dengan budak, dan perempuan dengan perempuan."

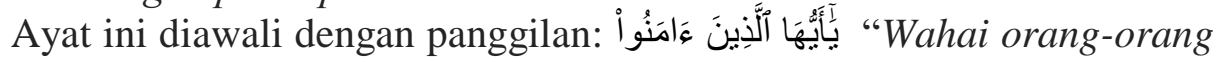
beriman..." yang mengindikasikan adanya hukum yang akan diterangkan. Dari panggilan tersebut seolah-olah Allah swt. Mengatakan, "Karena kamu telah beriman kepada-Ku, maka dengarkanlah perintah (taklif) berikut ini: كُتِبَ عَلَيَكُمُ

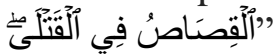

"Diwajibkan atas kalian menjalankan qishash atas pembunuhan." Maksudnya Allah mewajibkan orang beriman agar melaksanakan qishash sebagaimana kewajiban melaksanakan shallat dan puasa. ${ }^{10}$

Secara umum ayat tersebut mengintruksikan kepada orang beriman, agar menjalankan qishash dengan nilai keadilan, sebanding, yaitu membunuh dengan dibunuh, laki-laki dengan laki-laki, wanita dengan wanita, merdeka dengan merdeka, budak dengan budak, akan tetapi bila pihak keluarga korban memaafkannya, maka pihak pembunuh harus membayar diyat kepada pihak terbunuh dengan baik.

Menurut Muhammad al-Mutawalli al-Sya'rawi, kata: "كتب" "kutiba" pada ayat tersebut mengindikasikan keterlibatan orang-orang beriman dalam pelaksanaan ketetapan hukum ini. Berbeda dengan kata "Kataba" pada " كتب الله "Allah telah menetapkan Aku dan Rasul-Ku pasti menang," yang lebih kepada menunjukkan tidak terdapatnya peran serta manusia dalam kemenangan yang tercantum di dalamnya. ${ }^{11}$

Lebih lanjut Muhammad Sya'rawi menegaskan, bahwa kata "kutiba" mengindikasikan adanya kemaslahatan. Hal ini terlihat dari kelanjutan ayat tersebut berupa penetapan sanksi qishash kepada pembunuh yang dengannya lahir sebuah kemaslahatan bagi keluarga terbunuh dengan dapat menuntut. Begitu juga sebaliknya, karena setiap orang bisa menjadi si pembunuh atau yang terbunuh. Ketika ia menjadi si pembunuh, maka ia harus rela menerima qishash sebagai balasannya. Dan bagi si terbunuh, qishash merupakan kemaslahatan baginya. Dengan demikian syari'at itu menyentuh ke seluruh lapisan masyarakat. ${ }^{12}$

Sedangkan diyat adalah ganti rugi akibat dari suatu perbuatan pidana (Jinayah). Misalnya, orang yang membunuh dengan tidak sengaja dihukum dengan diyat berupa memerdekakan hamba sahaya dan membayar 100 ekor

${ }^{9}$ Abu al-Fida' Isma'il ibnu Umar bin Katsir, Tafsir al-Qur'an al- 'Azhim, Dar Thaibah Linnasyar wa al-Tauzi, 1999, h. 489.

${ }^{10}$ Abu Ja'far al-Thabari, Jami 'ul Bayan fi Ta'wil al-Qur'an, t.tp, Mu'assasah alRisalah, 2000, Juz III, hal. 357.

${ }^{11}$ Muhammad al-Mutawalli al-Sya'rawi, Tafsir al-Sya'rawi, T.tp, t.t., Jilid V, hal. 758.

${ }^{12}$ Sya'rawi, Tafsir al-Sya'rawi, hal. 758. 
unta kepada keluarga korban. Diyat diatur dalam al-Quran yaitu: QS. al-Nisa, $4: 92$

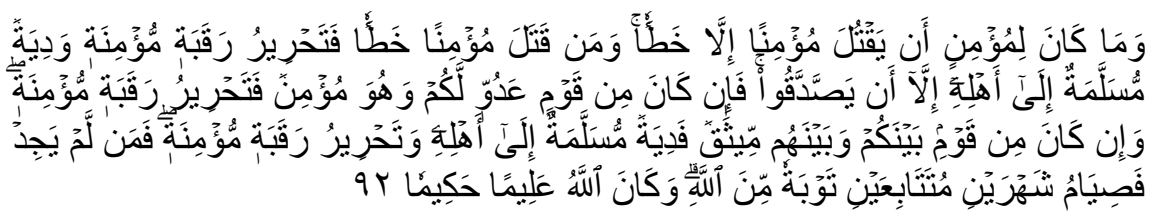

"Dan tidak layak bagi seorang mukmin membunuh seorang mukmin (yang lain), kecuali karena tersalah (tidak sengaja), dan barangsiapa membunuh seorang mukmin karena tersalah (hendaklah) ia memerdekakan seorang hamba sahaya yang beriman serta membayar diat yang diserahkan kepada keluarganya (si terbunuh itu), kecuali jika mereka (keluarga terbunuh) bersedekah. Jika ia (si terbunuh) dari kaum (kafir) yang ada perjanjian (damai) antara mereka dengan kamu, maka (hendaklah si pembunuh) membayar diat yang diserahkan kepada keluarganya (si terbunuh) serta memerdekakan hamba sahaya yang beriman. Barangsiapa yang tidak memperolehnya, maka hendaklah ia (si pembunuh) berpuasa dua bulan berturut-turut untuk penerimaan taubat dari pada Allah. Dan adalah Allah Maha Mengetahui lagi Maha Bijaksana."

\section{Jarimah Had}

Jarimah had/hudud, adalah tindak pidana yang di dikenai hukuman had, yakni hukuman yang telah ditentukan macam dan jumlah (berat-ringan) sanksinya yang menjadi hak Allah swt. dan tidak dapat diganti dengan macam hukuman lain atau dibatalkan sama sekali oleh manusia. Jarimah hudud merupakan kejahatan yang dalam pidana kerena terkait dengan kepentingan publik.

Jumhur 'Ulama telah merumuskan macam-macam jarimah hudud, yaitu: zina, qadzaf (tuduhan palsu zina), sariqah (koropsi/mencuri), hirabah (merampok), riddah (murtad), al-baghy (pembrontak) dan surb al-khamr (minum khamr).

\section{Jarimah Takzir}

Jaraimul Takzir adalah kejahatan yang dapat dikenai takzir. Jenis dan hukumannya sanksinya secara penuh ada pada wewenang penguasa (keputusan hakim) demi terealiasinya kemaslahatan umat. Dalam hal ini unsur akhlak menjadi pertimbangan paling utama. Dalam penetapannya prinsip utama yang mejadi acuan penguasa adalah menjaga kepentingan umum dan melindungi setiap anggota masyarakat dari kemadhorotan (bahaya), serta penegakannya harus sesuai dengan prinsip syar'i. Misalnya takzir atas maksiat, kemaslahatan umum, pelanggaran terhadap lingkungan hidup, pelanggaran lalu lintas, dan lain-lain. 


\section{Macam-macam Hukuman Tindak Pidana \\ 1. Tindak pidana yang dikenai Qishash atau Diyat}

Tindak pidana yang termasuk dalam Jinayah dapat dikenai qishash atau diyat adalah pembunuhan. Definisi pembunuhan adalah perbuatan menghilangkan nyawa orang lain.

Pembunuhan pada asalnya terbagi menjadi 2 (dua) macam,yaitu: 1) Pembunuhan yang diharamkan, seperti pembunuhan karena permusuhan. 2) Pembunuhan yang hak atau diperbolehkan, seperti pembunuhan dalam perang, atau pembunuhan terhadap orang murtad yang diperkenankan hukum.

Pembunuhan yang termasuk tindak pidana ada 3(tiga) macam, yaitu:

1) Pembunuhan dengan sengaja (قتل العمد)

Pembunuhan yang disengaja adalah pembunuhan yang diniatkan atau direncanakan dengan menggunakan alat atau cara yang dapat menyebabkan orang lain terbunuh. Pembunuhan yang disengaja merupakan perbuatan yang diharamkan dan pelakunya memikul dosa besar (kabair), sebagaimana firman Allah: QS. Al-Isra':33

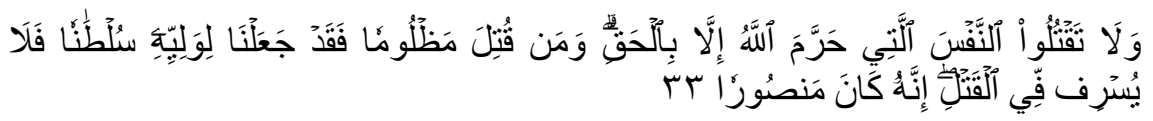

"Dan janganlah kamu membunuh jiwa yang diharamkan Allah (membunuhnya), melainkan dengan suatu (alasan) yang benar. Dan barangsiapa dibunuh secara zalim, maka sesungguhnya Kami telah memberi kekuasaan kepada ahli warisnya, tetapi janganlah ahli waris itu melampaui batas dalam membunuh. Sesungguhnya ia adalah orang yang mendapat pertolongan."

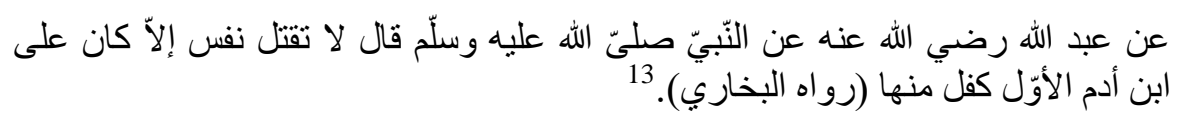

"Dari Abdullah ra. dari Nabi saw.bersabda: "Tidaklah seseorang membunuh, melainkan anak adam pertama (Qabil) turut menanggung dosanya”. (HR. Bukhari).

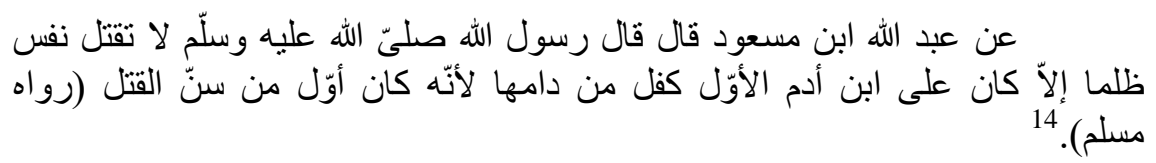

${ }^{13}$ Abu Abdillah Muhammad bin Ismail bin Ibrahim bin Mugirah al-Bukhari, Shahih al-Bukhari, Bairud: Dar al-Fikr, 1981M/ 1401H,1981M/ 1401H, Juz 7, h. 35

${ }^{14}$ Abu Husain Muslim Ibnu Hajaj al-Qusyairi al-Naisyaburi, Shahih Muslim, Bairud: Dar al-Fikr, 1993M/1414H, J.2,,h. 100. 
"Dari Abdullah bin Mas'ud berkata: Rasulullah saw bersabda: "Setiap kali terjadi pembunuhan seseorang secara zalim, maka putra adam yang pertama ikut bertanggung jawab terhadap darahnya, karena dia manusia pertama kali yang melakukan pembunuhan". (HR. Muslim).

Hukuman maksimal bagi pelaku pembunuhan yang secara disengaja yaitu di-qishash, sebagaiman dalam firman-Nya QS. al-Baqarah, 2:178

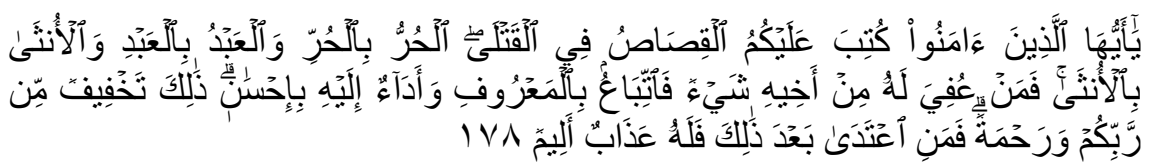

"Hai orang-orang yang beriman, diwajibkan atas kamu qishaash berkenaan dengan orang-orang yang dibunuh; orang merdeka dengan orang merdeka, hamba dengan hamba, dan wanita dengan wanita. Maka barangsiapa yang mendapat suatu pemaafan dari saudaranya, hendaklah (yang memaafkan) mengikuti dengan cara yang baik, dan hendaklah (yang diberi maaf) membayar (diat) kepada yang memberi maaf dengan cara yang baik (pula). Yang demikian itu adalah suatu keringanan dari Tuhan kamu dan suatu rahmat. Barangsiapa yang melampaui batas sesudah itu, maka baginya siksa yang sangat pedih."

Para 'Ulama (Fuqaha dan Mufassir) sepakat, bahwa qishash diberlakukan untuk kategori pembunuhan yang disengaja, tetapi mereka berbeda pemahaman tentang bentuk pembunuhan sengaja tersebut. Apakah orang merdeka diqishash dengan membunuh budak, muslim membunuh kafir /dzimmi?

Imam Abu Hanifah berpandangan, bahwa ayat tersebut bersifat umum untuk seluruh pembunuhan, baik pembunuhan yang dilakukan seorang merdeka dan sebailknya, ataupun seorang dzimmi kepada muslim dan sebaliknya. ${ }^{15}$ Menurut Abu Hanifah ayat 178 al-Baqarah terdapat penggalan kalimat yang terpisah, sempurna dan dapat berdiri sendiri, yaitu:

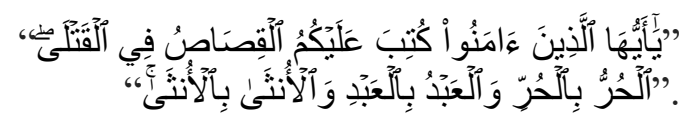

Kalimat pertama merupakan kalimat umum menjelaskan tentang qishash, sedangkan kalimat kedua merupakan penjelasan atau penyangkalan terhadap kekeliruan orang Jahiliyah pada saat itu melakukan pembalasan yang tidak seimbang, sebagaimana yang terdapat pada asbabul nuzul ayat ini. Ayat ini bukan merupakan

15 'Ali al-Sais, Tafsir Ayat Ahkam, Bairud: Dar al-Qahirah, t.t, Jilid II, hal. 131. 
pembatasan status sebagai hamba dengan hamba, melainkan pembatasan satu banding satu. ${ }^{16}$

Sementara menurut Jumhur 'Ulama (Malik, Syafi'i dan Hambali) berpendapat, bahwa seorang merdeka tidak boleh di-qishash karena membunuh hamba sahaya. Dari ayat 178 surat al-Baqarah terdapat pengertian, bahwa Allah mewajibkan persamaan karena di antara makna qhisash itu sendiri adalah seimbang. Adapun mengenahi

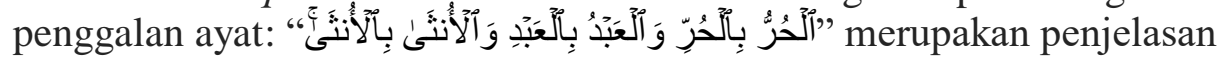
selanjutnya dari makna seimbang untuk penjelasan awal ayat. Dengan kata lain ayat tersebut harus difahami secara menyatu. Oleh karena di antara orang merdeka dengan hamba sahaya tidak seimbang, maka orang merdeka yang membunuh hamba sahaya tidak dapat di-qishash. ${ }^{17}$ Jumhur 'Ulama dan Imam Qurtubi juga berpendapat, bahwa orang muslim tidak di-qishash karena membunuh orang kafir sebagaimana hadits nabi saw:

$$
\text { لا يقتل مسلم بكافر. (رواه البخاري). }
$$

"Tidak dibunuh seorang muslim karena membunuh orang kafir" (HR. Bukhari). ${ }^{18}$

Namun apabila keluarga (ahli waris) korban memaafkan, pembunuh diharuskan membayar diyat senilai 100 (seratus) ekor unta secara tunai, sebagaimana sabda Nabi:

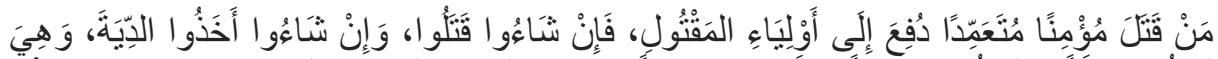

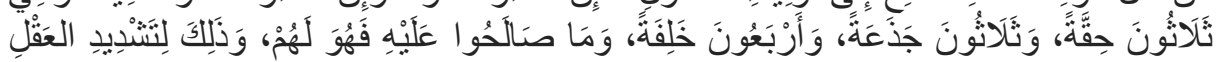

"Barangsiapa yang membunuh dengan sengaja, maka ia diserahkan kepada keluarga terbunuh. Apabila mereka menghendaki, maka (membalas) membunuhnya, dan apabila mereka menghendaki ambillah diyat, yaitu tiga puluh ekor unta hiqqah, tiga pukuh ekor unta jadzaah, dan empat puluh ekor unta khalafah. Hasil perdamaian itu untuk mereka (ahli waris). Demikian itu untuk menakutkan terhadap pembunuhan. (HR. Tirmidzi).

Ibnu al-Qayyim menyatakan, "Pembunuhan dengan sengaja, berhubungan dengan tiga hak, yaitu: Hak Allah, dan ini akan terhapus dengan bertaubat. Hak auliya` al-maqthul, dan ini gugur dengan

${ }^{16}$ Ali al-Sais, Tafsir Ayat Ahkam, hal. 131.

${ }^{17} \mathrm{Abu}$ 'Abdullah Muhammad bin Ahmad al-Anshari al-Qurthubi, al-Jami' al-Ahkam al-Qur'an, Cairo: Dar al-Hadits, t.t., Juz IX, hal. 636-637.

${ }^{18}$ al-Qurthubi, al-Jami' al-Ahkam al-Qur'an, hal. 636-637. 
menyerahkan diri kepada mereka. Hak al-maqthul (korban). Ini tidak gugur, karena korban telah mati dan hilang. Namun, apakah kebaikan pembunuh akan diambil di akhirat atau Allah Subhanahu wa Ta'ala dengan keutamaan dan kemurahan-Nya akan menanggungnya? Yang benar adalah, Allah dengan keutamaannya akan bertanggung jawab, apabila si pembunuh tersebut jelas kebenaran dan kejujuran taubatnya."

Apabila pembunuh telah menyerahkan diri dengan suka rela, dengan menyesalinya dan takut kepada Allah, serta bertaubat dengan taubat nashuha, maka hak Allah Subhanahu wa Ta'ala gugur dengan taubat si pembunuh, dan hak auliya' al-maqthul gugur dengan menunaikan qishash secara sempurna, dengan jalan perdamaian, atau dimaafkan. Akan tetapi, masih tersisa hak kurban. Allah yang akan menggantinya di hari kiamat dari hamba-Nya yang bertaubat, dan Allah pun memperbaiki hubungan keduanya.

Hukuman qishash bagi pelaku kejahatan pembunuhan merupakan hukuman yang layak dijatuhkan kepada pelaku. Nyawa manusia adalah milik Allah dan pemeliharaan terhadap nyawa adalah kewajiban manusia. Hukum qishash adalah alat untuk melindungi nyawa manusia dari kematian yang tidak dikehendaki-Nya, sebagaimana dalam firman-Nya: QS. al-Baqarah, 2:179

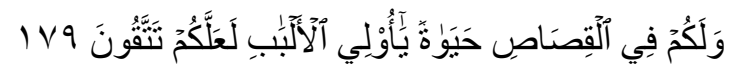

"Dan dalam qishaash itu ada (jaminan kelangsungan) hidup bagimu, hai orang-orang yang berakal, supaya kamu bertakwa."

Qishash diberlakukan agar peristiwa pembunuhan tidak terjadi, sehingga kelangsungan hidup akan terjamin dan terlindungi.

\section{2) Pembunuhan tidak sengaja (قتل الخطاء)}

Pembunuhan tidak sengaja adalah pembunuhan yang tidak dimaksudkan untuk membunuh, karena salah sasaran, atau ketidaktahuan pelaku sehingga secara tidak sengaja menghilangkan nyawa orang lain. Pelaku pembunuhan ini tidak dikenakan qishash, melainkan diwajibkan membayar diyat dengan cara memerdekakan hamba sahaya dan memberi 100 (seratus) ekor unta kepada keluarga atau ahli waris korban, sebagaimana firman Allah swt: QS. al-Nisa, 4:92

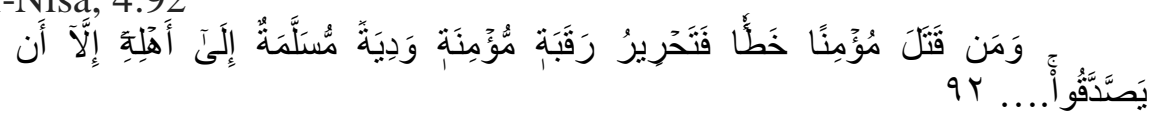

"Dan barangsiapa membunuh seorang mukmin karena tersalah (hendaklah) ia memerdekakan seorang hamba sahaya yang beriman serta membayar diyat yang diserahkan kepada keluarganya (si terbunuh itu), kecuali jika mereka (keluarga terbunuh) bersedekah. ' 
Diyat yang dimaksud dalam ayat di atas dijelaskan dalam sabda Rasul saw:

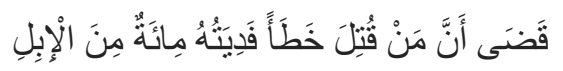

"Sesungguhnya diyatnya pembunuhan jiwa adalah 100

ekor unta". (HR. Abu Daud, Nasai dan Ibn Huzaimah)

\section{3) Pembunuhan seperti sengaja (قتل شبه العمد)}

Pembunuhan seperti sengaja adalah pembunuhan yang dilakukan tidak sengaja dan tidak menggunakan alat dan cara yang dapat membunuh, dan yang secara kebiasaan tidak dimaksudkan hendak membunuh. Misalnya seseorang memukul dengan lidi dan yang dipukul ternyata mati. Pelaku pembunuhan ini tidak dihukum qishash, tetapi harus membayar diyat.

\section{Tindak Pidana yang dikenahi had}

Tindak pidana yang dapat dikenai Had adalah: 1) Zina, homoseksual, lesbianisme, dan bestiality.

Berzina termasuk dosa besar dan harus dihukum sesuai dengan ketentuan hukum ( $\mathrm{Had}$ ). Ada 2 (dua) macam kategora berzina, yaitu zina yang dilakukan oleh orang yang pernah menikah dan oleh orang yang belum menikah. Pelaku zina yang pernah menikah apabila terbukti dikenai hukuman setinggi-tingginya rajam. Sedangakan bagi pelaku zina yang belum pernah menikah hukumannya dipukul (jilid) 100 (seratus) kali pukulan dan diasingkan selama 1 (satu) tahun. Firman Allah swt. QS. al- Nur, 24:2

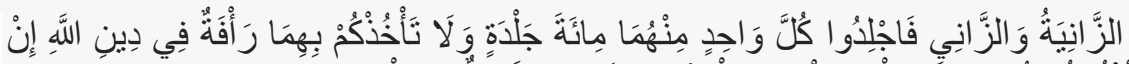

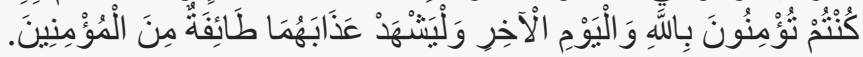

"Perempuan yang berzina dan laik-laki yang berzina, maka deralah tiap-tiap seorang dari keduanya seratus kali dera, dan janganlah belas kasihan kepada keduanya mencegah kamu untuk (menjalankan) agama Allah, jika kamu beriman kepada Allah, dan hari akhirat, dan hendaklah (pelaksanaan) hukuman mereka disaksikan sekumpulan dari orang-orang yang beriman"

Hukuman berat bagi pelaku perzinaan dan pelaksanaanya disaksikan orang banyak, mengandung arti hukuman itu merupakan upaya melindungi masyarakat, memberi pelajaran kepada masyarakat agar membenci perbuatan itu serta membuat orang menjadi takut berbuat kejahatan serupa. Dengan demikian hukuman ini bersifat preventif dan berfungsi memelihara ketenteraman dan ketertiban 
masyarakat. Hukum Islam lebih berpihak pada ketenteraman orang banyak dari pada memberi perlindungan kepada para pelaku kejahatan.

Homoseksual adalah melakukan hubungan seksual dengan sesama jenis yaitu laki-laki dengan laiki-laki. Apablia yang melakukannya perempuan dengan sesama perempuan disebut lesbianisme. Hukuman bagi pelaku homoseksual dan lesbianisme dikategorikan sama denga melakukan zina, karena itu jika dapat dibuktikan di pengadilan dapat diancam hukuman seperti halnya pelaku zina. Sebagaimana Sabda Nabi saw: adalah pezina."

"Kalau laki-laki bersenggama dengan laki-laki, keduanya

Demikian pula melakukan hubungan seksual dengan binatang (bestiality) termasuk perbuatan zina dan dikenai hukuman sebagaimana orang berzina. Islam sangat tegas dalam menghukum para pelaku perzinaan, karena dampaknya besar sekali terhadap tatanan kehidupan masyarakat, bahkan menjadi sumber penyakit yang dapat menghancurkan peradaban, seperti penyakit AIDS yang mampu membunuh jutaan orang pada waktu yang relatif singkat.

2) Menuduh zina (Qadzaf)

Menduduh berzina kepada orang lain apabila tuduhannya itu tidak bisa dibuktikan, maka penuduh dapat dikenai hukuman 80 (delapan puluh) kali pukulan. Sebagaimana Firman Allah swt. QS. AnNur, 24:4

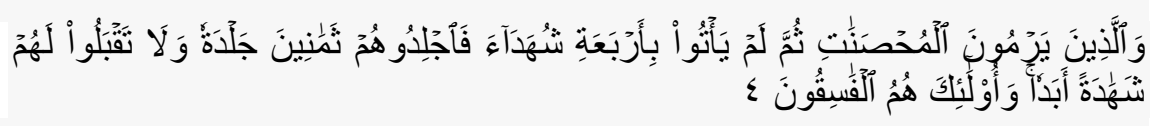

"Dan orang-orang yang menuduh wanita-wanita yang baik-baik (berbuat zina) dan mereka tidak mendatangkan empat orang saksi, maka deralah mereka (yang menuduh itu) delapan puluh kali dera, dan janganlah kamu terima kesaksian mereka buat selama-lamanya. Dan mereka itulah orang-orang yang fasik."

3) Minum Khamr

Khamr adalah minuman yang diharamkan, orang yang meminumnya berdosa. Minum khamr disamping berdosa yang hukumannya ditentukan di akhirat, juga dalam masyarakat muslim dipandang kejahatan yang patut dihukum. Hukuman yang diberikan adalah hukuman jilid 40 sampai 80 kali.

Hukuman berat bagi para peminum khamr dan pemabuk dimaksudkan untuk membuat jera dan tidak mengulanginya. Permabukan dapat merusak sistem syaraf sehingga pelakunya dapat lepas dari kontrol kesadarannya, sehingga dengan mudah dan ringan 
mereka dapat melakukan kejahatan lainnya seperti pencurian, pembunuhan, perzinaan, pemerkosaan, dan lain-lain. Selain menghukum berat para peminum khamr dan pemabuk, Islam juga mengharamkan pula penjualan minuman-minuman yang memabukkan.

4) Mencuri

Pencurian adalah mengambil barang milik orang lain tanpa izin pemiliknya secara sembunyi untuk dimilikinya. Hukuman bagi pelaku pencurian apabila dapat dibuktikan di pengadilan adalah potong tangan, sebagaimana firman Allah swt: QS. al-Maidah, 5:38

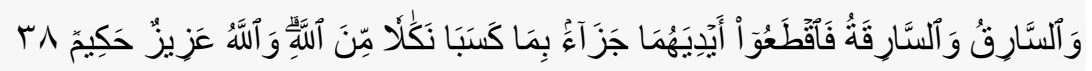

"Laki-laki yang mencuri dan perempuan yang mencuri, potonglah tangan keduanya (sebagai) pembalasan bagi apa yang mereka kerjakan dan sebagai siksaan dari Allah. Dan Allah Maha Perkasa lagi Maha Bijaksana.'

Islam menjamin hak kepemilikan dan hukum wajib memberikan perlindungan serta keamanan. Oleh sebab itu hukuman berat bagi pencurian merupakan upaya pemeliharaan dan perlindungan terhadap hak kepemilikan barang oleh individu maupun masyarakat.

\section{Peradilan Dalam Jinayah (Tindak Pidana)}

Penerapan hukum atas tindak pidana sebagaimana disebutkan di atas dilakukan melalu proses peradilan yang menyidangkan perkara-perkara. Dalam sejarah Islam, orang yang pertama memegang peradilan (hakim) adalah Rasulullah sendiri, selanjutnya sesuai dengan kebutuhan umat Islam yang berkembang terus menerus.

Hakim dipandang sebagai sebagai mujtahid, Islam memberikan nilainilai dasar yang harus dipegang oleh seorang hakim dalam memutuskan perkara. Seorang hakim dengan kekuasaannya dapat menjatuhkan hukuman kepada seseorang, oleh sebab itu hakim dituntut bertindak adil dalam memutuskan perkara.

Suatu perkara dapat digelar apabila ada dakwaan yang memenuhi ketentuan. Dakwaan adalah sesuatu yang menghubungkan kepada diri sendiri atas sesuatu yang ada pada orang lain atau dalam tanggungan orang lain. Dakwaan diakui apabila dikuatkan dengan ikrar (pengakuan), kesaksian, sumpah, atau dengan dokumen yang sah.

Ikrar adalah pengakuan terhadap apa yang didakwakan dan ini merupakan dalil yang paling kuat untuk menetapkan dakwaan. Sedangkan kesaksian adalah pemberitahuan seseorang tentang sesuatu yang dia ketahui. Kesaksian dapat berupa pengetahuan melalui penglihatan atau pendengaran. 
Kesaksian hukumnya menjadi fardu ain apabila seseorang dipanggil untuk itu dan dikhawatirkan kebenaran akan hilang. Firman Allah: QS.Al-Baqarah, 2:283

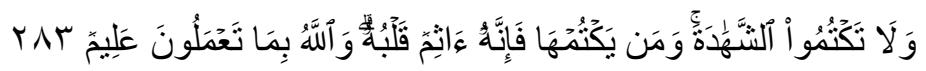

"Dan janganlah kamu (para saksi) menyembunyikan persaksian. Dan barangsiapa yang menyembunyikannya, maka sesungguhnya ia adalah orang yang berdosa hatinya; dan Allah Maha Mengetahui apa yang kamu kerjakan."

Kesaksian itu harus oleh 2 (dua) orang laki-laki, kecuali untuk kesaksian pada pidana zina atau tuduhan zina, saksinya harus 4 (empat) orang laki-laki, sebagaimana firman Allah: QS. al-Nisa' 4:15

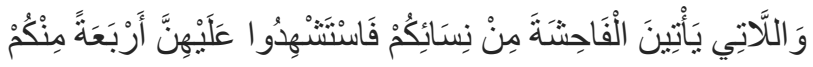

"Dan terhadap para wanita yang mengerjakan perbuatan keji, maka datangkanlah empat orang di antara kamu untuk menjadi saksi”.

Dan firman-Nya: QS. An-Nur, 24:4

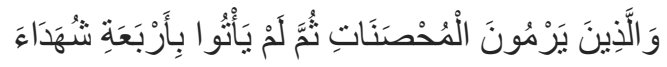

"Dan orang-orang yang menuduh wanita-wanita yang baik-baik berbuat zina, dan mereka tidak mendatangkan empat orang saksi."

Sumpah dalam hukum Islam dapat dijadikan bahan penetapan dakwaan yang berkaitan dengan harta benda (perdata). Sedangkan untuk pidana, sumpah tidak diterima sebagai alat pembuktian. Dalam menetapkan hukum pidana, peradilan Islam sangat hati-hati. Kesalahan dalam penetapan hukum dapat berakibat kerugian (untuk hukuman diyat) dan kecacatan (untuk hukuman potong tangan) dan bahkan kematian seseorang (untuk hukuman rajam atau qishash).

Pelaksanaan hukuman dilakukan dengan segera setelah pengadilan menetapkan hukuman bagi para pelaku. Ketentuan pelaksanaan hukuman dilaksanakan secara terbuka dan disaksikan orang banyak setelah selesai shallat Jumat. Hal ini dimaksudkan untuk menjadi pelajaran bagi seluruh masyarakat tentang hukumana bagi para pelaku kejahatan. Dengan demikian, tidak ada lagi orang yang mencoba meniru atau mengulangi perbuatan jahat. 
Hukuman yang berat tidak dimaksudkan sebagai balas dendam kepada para pelaku kejahatan, melainkan untuk menjaga agar kehidupan masyarakat aman dan tenteram. Oleh sebab itu, setiap pelaksanaan hukuman diumumkan kepada masyarakat agar peristiwa itu berkesan pada setiap orang dan berdampak pada pendidikan masyarakatnya. Setiap orang yang akan melakukan kejahatan akan berpikir kembali karena takut akan hukuman yang berat itu. Hukuman qishash bukanlah hukuman yang tanpa perikemanusiaan, justru merupakan hukuman yang melindungi hak-hak asasi manusia, karena para pelaku kejahatan telah menginjak-injak nilai-nilai kemanusiaan yang tinggi dan mulia.

\section{Kesimpulan}

Dari makalah yang diuraikan maka dengan ini penyusun dapat menyimpulkan sebagai berikut :

Hukum Pidana Islam disebut juga Jarimah bersal dari bahasa Arab (جريمة), yang berarti perbuatan dosa atau tindak pidana. Dalam terminologi hukum Islam, Jarimah dapat diartikan sebagai perbuatan-perbuatan yang dilarang menurut syara' dan ditentukan hukumannya oleh Allah, baik dalam bentuk sanksi-sanksi yang sudah jelas ketentuannya (had) maupun sanksisanksi yang belum jelas ketentuannya oleh Allah (ta'zir).

Jarimah dapat dibedakan menjadi dua hal, yaitu Jinayah dan Hudud. Jinayah membahas tentang pelaku tindak kejahatan beserta sanksi hukuman yang terkait dengan pembunuhan yang meliputi: qishash, diyat dan kafarat. Sedangkan hudud membahas tentang pelaku tindak kejahatan selain pembunuhan, yaitu: perihal penganiayaan beserta sanksi hukumannya yang meliputi: zina, qadzaf, murtad, mencuri, miras, merampok dan bughah (begal).

Sanksi hukuman (qishash, had dan tazir) terhadap pelaku tindak pidana bukan bertujuan untuk pelampiasan balas dendam, atau kebencian terhadap pelaku (pembunuh/penganiaya), melainkan sebagai pemenuhan hak Allah (secara vertikal), dan hak ahli waris terbunuh/ teraniaya (secara horizontal). Selain itu juga dapat menjadi sarana penghapusan dosa, memberikan efek jera, serta dapat melindungi kepentingan publik.

\section{Daftar Pustaka}

Al-Qur'an dan Terjemahannya, Depag RI.

'Audah, 'Abdul Qadir, al-Tasyri' al-Jina'I al-Islami, Bairud: Muassasah alRisalah, 1993.

al-Tasyri' al-Jina'I al-Islami, Bairud: Dar al-Kitab al-Arabi.

Ahmad Musa, Abu Hamid, al-Jaraim wa al-Uqubat fi al-Syari'ah alIslamiyah, Kairo: Jami'ah al-Azhar, 1975. 
Al-Asfahani, al-Raghib, Mufradat AlFazh al-Qur'an, Bairud: Dar alSyammiyah, t.t, cet. III.

Ahmad Jazuli, Fiqh Jinayah, Jakarta: PT RajaGrafindo Persada. Jakarta, 1999, cet-I.

Abdullah, Musthafa. dkk, Intisari Hukum Pidana, Jakarta: Ghalia Indonesia, 1983.

Bukhari-al, Abu Abdillah Muhammad bin Ismail bin Ibrahim bin Mugirah, Shahih al-Bukhari, Bairud: Dar al-Fikr, 1981M/ 1401H,1981 M/ 1401H Hasballah, Ali, Ushul al-Tasyri' al-Islami, Mesir: Dar al-Ma'arif, t.t.,

Ibnu Katsir, Abu al-Fida' Isma'il ibnu Umar, Tafsir al-Qur'an al- 'Azhim, Dar Thaibah Linnasyar wa al-Tauzi, 1999.

Ibnu Manzur, Lisan al- 'Arab, Bairud: Dar Shadir, t.t, Juz VII.

Khalaf, 'Abdul Wahab, 'Ilmu Ushul Fiqh, Kairo: Dar al-Hadits, 2003M/ 1423H. ,'Ilmu Ushul al-Fiqh, al- Dar Al Kuwaitiyah, 1968, cet-VIII.

Muhammad bin Shalih Ibnu Utsaimin, Asy-Syarhu al-Mumti' 'ala Zad alMustaqni', KSA: Dar Ibnu al-Jauzi, tahun 1428 H, cet- I.

Muhammad Ali, Tafsir Ayat al-Ahkam, Bairud: Dar ibnu Katsir, t.t, Jilid II.

Muslich, Ahmad Wardi. Pengantar dan Asas Hukum Islam. Jakarta: Sinar Grafika, 2004.

Naisyaburi-al, Abu Husain Muslim Ibnu Hajaj al-Qusyairi, Shahih Muslim, Bairud: Dar al-Fikr, 1993 M/1414 H.

Qurthubi-al, Abu 'Abdullah Muhammad bin Ahmad al-Anshari, al-Jami' alAhkam al-Qur'an, Cairo: Dar al-Hadits, t.t., Juz IX.

Shan'ani-al, Muhammad bin Isma'il, Subul as-Salam al-Mushilah ila Bulugh al-Maram, KSA: Dar Ibnu al-Jauzi, 1428 H, cet. VIII.

Sya'rawi-al, Muhammad al-Mutawalli, Tafsir al-Sya'rawi, T.tp, t.t., Jilid V.

Sais-al, 'Ali, Tafsir Ayat Ahkam, Bairud: Dar al-Qahirah, t.t, Jilid II.

Thabari-al, Abu Ja'far, Jami'ul Bayan fi Ta'wil al-Qur'an, t.tp, Mu'assasah alRisalah, 2000, Juz III 